\title{
Jabuticaba residues (Myrciaria jaboticaba (Vell.) Berg) are rich sources of valuable compounds with bioactive properties
}

\author{
Bianca R. Albuquerque ${ }^{\mathrm{a}, \mathrm{b}}$, Carla Pereira ${ }^{\mathrm{a}}$, Ricardo C. Calhelha ${ }^{\mathrm{a}}$, Maria José Alves $^{\mathrm{a}}$, \\ Rui M.V. Abreu ${ }^{\mathrm{a}}$, Lillian Barros ${ }^{\mathrm{a}, *}$, M. Beatriz P.P. Oliveira ${ }^{\mathrm{b}}$, Isabel C.F.R. Ferreira ${ }^{\mathrm{a}, *}$ \\ ${ }^{a}$ Centro de Investigação de Montanha (CIMO), Instituto Politécnico de Bragança, Campus de Santa Apolónia, 5300-253 Bragança, Portugal \\ ${ }^{\mathrm{b}}$ REQUIMTE - Science Chemical Department, Faculty of Pharmacy, University of Porto, Rua Jorge Viterbo Ferreira $n^{\circ} 228,4050-313$ Porto, Portugal
}

\section{A R T I C L E I N F O}

\section{Keywords:}

Anthocyanins

Hydrolysable tannins

Anti-proliferative

Antimicrobial

Antioxidant activity

\begin{abstract}
A B S T R A C T
Jabuticaba (Myrciaria jaboticaba (Vell.) Berg) is a Brazilian berry, very appreciated for in natura consumption. However, its epicarp is not normally consumed due to its stiffness and astringent taste, and in manufacture of products from jabuticaba fruit, it is responsible for the generation of large amounts of residues. The exploration of by-products is becoming important for the obtainment of valuable bioactive compounds for food and pharmaceutical industries. In this context, jabuticaba epicarp was studied regarding its chemical composition, namely in terms of phenolic compounds, tocopherols, and organic acids, and its bioactive properties, such as antioxidant, anti-proliferate, anti-inflammatory, and antimicrobial activities. A total of sixteen phenolic compounds, four tocopherols and six organic acids were identified in jabuticaba epicarp. Regarding bioactive properties, it showed high antioxidant activity, also presenting moderate anti-inflammatory, anti-proliferative, and antimicrobial activities. The extract did not present hepatotoxicity, confirming the possibility of its applications without toxicity issues.
\end{abstract}

\section{Introduction}

Myrciaria jaboticaba (Vell.) Berg, belonging to the Myrtaceae family, is a native species to Brazil, namely from Atlantic Rainforest biome, but also widely growing in the whole country, it blooms between March and October (de Neves, Stringheta, Gómez-Alonso, \& HermosínGutiérrez, 2018; Oliveira, Angelotti-Mendonça, Tanaka, da Silva, \& Scarpare Filho, 2019). Its fruits, commonly known as jabuticaba or Brazilian berries, are small berries with a diameter of $3-4 \mathrm{~cm}$ that contain between one and four small seeds, with thick green to dark violet skin, depending on the ripening stage, that is not commonly consumed. On the other hand, the fruit gelatinous pulp presents a sweet and astringent taste due to its high content of sugars and acids, being very appreciated for in natura consumption or as fruit pulp preparation (Oliveira et al., 2019). The consumption of jabuticaba has been associated with diverse health benefits that are linked to its chemical composition with great polyphenol abundance (Donado-Pestana et al., 2018; Wu, Hung, Shin, Wang, \& Huang, 2016).

However, the commercialization of this kind of berry is difficult due to its high perishability, which justifies its application in the production of jam, syrups, liqueur, and other alcoholic beverages. Nevertheless, the residues (epicarp and seeds) inherent to the production of such foodstuff and beverages represent about $50 \%$ of the total processed volume (Morales et al., 2016), and the fact is that jabuticaba epicarp residue is rich in phenolic compounds, such as anthocyanins and ellagic acid derivates (Morales et al., 2016; Neri-Numa, Soriano Sancho, Pereira, \& Pastore, 2018). These characteristics have been attracting the attention of academia and food industry that consider its use as a food additive or ingredient, for example, some studies have reported the application of this by-product to improve sensory characteristics of meat products (Almeida et al., 2015; Baldin et al., 2016, 2018), and also to increase the nutritional value, namely carbohydrate and fibre content, of bakery products (Marquetti et al., 2018). Besides, the addition of $M$. jaboticaba to food products also conferred them increased antioxidant activity (Almeida et al., 2015; Baldin et al., 2016; Marquetti et al., 2018) and antimicrobial action (Baldin et al., 2016). Moreover, M. jaboticaba epicarp has also been explored by some authors for the prevention of cardio, neurodegenerative, and chronic diseases, with these benefits possibly ascribed to its antioxidant and anti-inflammatory potential (Plaza et al., 2016; Zhao et al., 2019). However, its chemical composition is still poorly elucidated, and the characterization of such residues can play crucial roles in the valorization of natural resources that

\footnotetext{
* Corresponding authors.

E-mail addresses: lillian@ipb.pt (L. Barros), iferreira@ipb.pt (I.C.F.R. Ferreira).
} 
are usually discarded, contributing to the creation of more economically and socially sustainable productive chains (Ravindran \& Jaiswal, 2016). With that in mind, the present work aims to provide detailed data concerning the chemical composition of $M$. jaboticaba epicarp, namely in terms of organic acids, tocopherols, and phenolic compounds. Furthermore, the bioactive potential of the hydroethanolic extracts was also assessed in terms of cytotoxicity, hepatotoxicity, antioxidant, anti-inflammatory, and antimicrobial properties.

\section{Material and methods}

\subsection{Sample preparation}

Jabuticaba (Myrciaria jaboticaba (Vell.) Berg) fruits were acquired in CEAGESP - Brazil from a farm producer "Unidos". The fruits were washed and the epicarp was manually separated from the pulp. The epicarp was frozen at $-18^{\circ} \mathrm{C}$ and lyophilized by the Instituto Mauá de Tecnologia (Brazil). The dried epicarp was sent to Centro de Investigação de Montanha (CIMO), located at the Polytechnic Institute of Bragança (IPB), Portugal, where it was reduced to a fine and homogeneous powder and stored at $-20^{\circ} \mathrm{C}$ until the analyses were performed.

\subsection{Chemical characterization}

\subsubsection{Phenolic compounds}

2.2.1.1. Non-anthocyanin compounds. The powdered sample $(5 \mathrm{mg})$ was extracted with $65 \mathrm{ml}$ of an ethanol:water solution $(80: 20 \mathrm{v} / \mathrm{v})$ under stirring for $1 \mathrm{~h}$, the mixture was then filtered through filter paper (Whatman No. 4) and the epicarp residue was re-extracted for 1 additional hour. The combined filtrates were evaporated under reduced pressure at $40^{\circ} \mathrm{C}$ (rotary evaporator Büchi R-210, Flawil, Switzerland) until total removal of ethanol and were subsequently frozen and lyophilized.

For further identification of the compounds, a purification step was performed using a C-18 SepPak $^{\circledR}$ Vac 3 cartridge (Phenomenex, Torrance, CA, USA), activated with $5 \mathrm{ml}$ of ethanol followed by $5 \mathrm{ml}$ of water. Then $5 \mathrm{ml}$ of re-dissolved lyophilized extract in water $(40 \mathrm{mg}$ / $\mathrm{ml}$ ) was loaded into the cartridge. The removal of compounds that may interfere with the analysis of phenolic compounds (such as sugars) was done with $5 \mathrm{ml}$ of water. The purified extract was then recovered with $5 \mathrm{ml}$ of ethanol. Afterwards, the solvent was evaporated under reduced pressure at $35^{\circ} \mathrm{C}$, the extract was dissolved in $2 \mathrm{ml}$ of ethanol:water $(80: 20, \mathrm{v} / \mathrm{v})$, and filtered through a $0.22 \mu \mathrm{m}$ nylon filter.

The purified extract was analysed by high performance liquid chromatography (Dionex Ultimate 3000 UPLC, Thermo Scientific, San Jose, CA, USA), with a diode-array detector $(280,330$, and $370 \mathrm{~nm}$ wavelengths) linked to an electrospray ionization mass spectrometry working in negative mode (Linear Ion Trap LTQ XL, Thermo Scientific, San Jose, CA, USA) as described by Bessada, Barreira, Barros, Ferreira, and Oliveira (2016).

Data were collected and analysed using the Xcalibur ${ }^{\circledR}$ program (ThermoFinnigan). Results were expressed as $\mathrm{mg}$ per $\mathrm{g}$ of extract and mg per $g$ of epicarp dry weight $(\mathrm{dw})$.

2.2.1.2. Anthocyanin compounds. The powdered sample (1 mg) was extracted with $30 \mathrm{ml}$ of an ethanol:water solution $(80: 20 \mathrm{v} / \mathrm{v})$ acidified with $0.1 \%$ citric acid $(1 \mu \mathrm{M})$, by stirring for $1 \mathrm{~h}$ protected from light. After filtration through filter paper (Whatman No. 4), the residue was re-extracted $(1 \mathrm{~h})$ and the combined filtrates were evaporated under reduced pressure at $40{ }^{\circ} \mathrm{C}$ and subsequently lyophilized.

The lyophilized extract $(10 \mathrm{mg})$ was re-dissolved in $2 \mathrm{ml}$ of ethanol:water $(80: 20 \mathrm{v} / \mathrm{v})$ and filtered through a $0.22 \mu \mathrm{m}$ disposable filter disk into an amber vial for HPLC analysis. The analysis was made using a Dionex Ultimate 3000 HPLC (Thermo Scientific) system equipped with a quaternary pump, an automatic injector (at $5^{\circ} \mathrm{C}$ ), a degasser, and an automated thermostat column compartment. The detection of the compounds was carried out with a DAD, using wavelengths of $520 \mathrm{~nm}$ and coupled to a mass spectrometry detector (HPLC-DAD-ESI/MS), operating under the conditions thoroughly described by Gonçalves et al. (2017). Data were collected and analysed using the Xcalibur ${ }^{\circledast}$ program (Thermo Finnigan). Results were expressed as mg per $\mathrm{g}$ of extract and mg per $g$ of epicarp dry weight (dw).

\subsection{Organic acids}

Organic acids were extracted from the freeze-dried epicarp using a methodology previously described by Barros et al. (2013) with some modifications. Samples $(1.5 \mathrm{~g})$ were extracted by stirring with $25 \mathrm{ml}$ of meta-phosphoric acid $\left(25^{\circ} \mathrm{C}\right.$ at $\left.150 \mathrm{rpm}\right)$ for $25 \mathrm{~min}$ protected from light and subsequently filtered through Whatman No. 4 paper. Before analysis, samples were filtered through $0.22 \mu \mathrm{m}$ nylon filters. The analysis was performed following the methodology described by Barros et al. (2013). The results were expressed in $\mathrm{mg}$ per $100 \mathrm{~g}$ of epicarp dry weight (dw).

\subsection{Tocopherols}

For tocopherols analysis, a methodology previously described by Barros et al. (2013) was followed, using a high performance liquid chromatography system coupled to a fluorescence detector (HPCL-FL; Knauer, Smartline system 1000, Berlin, Germany). Authentic standards of tocopherol isoforms ( $\alpha$-, $\beta-, \gamma$-, and $\delta$-) (Sigma, St. Louis, MO, USA) and tocol (Matreya, Pleasant Gap, PA, USA) were used for quantification. Data were collected and analysed using the Clarity 2.4 software (DataApex, Prague, Czech Republic). The results were expressed in $\mathrm{mg}$ per $100 \mathrm{~g}$ of dry weight (dw).

\subsection{Evaluation of bioactive properties}

\subsubsection{Cell-based antioxidant activity}

2.5.1.1. Inhibition of lipid peroxidation through thiobarbituric acid reactive species (TBARS). The lipid peroxidation inhibition in porcine (Sus scrofa) brain homogenates was evaluated by measuring the formation of thiobarbituric acid reactive substances (TBARS), according to a previously described methodology Corrêa et al. (2015). The result was expressed as $\mathrm{EC}_{50}$ value, which correspond to the extract concentration that provides $50 \%$ of antioxidant activity $(\mu \mathrm{g} / \mathrm{ml})$. Trolox was used as positive control.

2.5.1.2. Oxidative haemolysis inhibition assay (OxHLIA). The antihaemolytic activity of jabuticaba epicarp extract was evaluated by the oxidative haemolysis inhibition assay (OxHLIA), as described in detail by Lockowandt et al. (2019). The results were expressed as IC $_{50}$ values $(\mu \mathrm{g} / \mathrm{ml})$, meaning the extract concentration able to promote a $\Delta \mathrm{t}$ haemolysis delay of 120 and $180 \mathrm{~min}$. Trolox was used as positive control.

\subsubsection{Anti-inflammatory activity}

The anti-inflammatory activity was evaluated by LPS-induced nitric oxide (NO) production by mouse macrophages RAW 264.7, following the procedure described by Corrêa et al. (2015). Negative control was prepared without the addition of LPS to observe their possible effect on the basal levels of NO. For the positive control, Dexamethasone $(50 \mu \mathrm{M})$ was used. The results were expressed as $\mathrm{IC}_{50}$ value $(\mu \mathrm{g} / \mathrm{ml})$, which correspond the concentration that induces $50 \%$ of inhibition of the NO production.

\subsubsection{Anti-proliferative activity and hepatotoxicity}

The cytotoxic activity of the jabuticaba epicarp extract was performed on four human tumor cell lines: NCI-H460 (lung carcinoma); 
MCF-7 (breast carcinoma); HepG2 (hepatocellular carcinoma); and HeLa (cervical carcinoma); and one non-tumor liver cells primary culture obtained from porcine liver (PLP2). The analysis was performed for each of the dilutions of the extract following the Sulforodamine B (SRB) assay, as previously described by Corrêa et al. (2015). The results were expressed as $\mathrm{GI}_{50}$ value $(\mu \mathrm{g} / \mathrm{ml})$, which correspond to the concentration of extract that inhibited $50 \%$ of cell proliferation.

\subsubsection{Antimicrobial activity}

For the antimicrobial activity, the jabuticaba epicarp extract was tested against five Gram-negative bacteria (Escherichia coli, Klebsiella pneumoniae, Morganella morgannim, Proteus mirabilis, and Pseudomonas aeruginosa) and three Gram-positive bacteria (Enterococcus faecalis, Listeria monocytogenes, and Methicillin-resistant Staphylococcus aureus (MRSA)). The bacteriostatic action of the jabuticaba extract was established following a methodology described by Pires et al. (2018) and the results were expressed as MIC ( $\mathrm{mg} / \mathrm{ml}$ ), which correspond to the minimal inhibitory concentration for cell multiplication. The bactericidal action was determined according to Corrêa et al. (2015) and the results were expressed as $\mathrm{MBC}$ value $(\mathrm{mg} / \mathrm{ml})$, meaning the minimal bactericidal concentration. Ampicillin was used as negative control for all bacteria while Imipenem was used for all Gram-negative bacteria and for L. monocytogenes, and Vancomycin was used only for E. faecalis and MRSA.

\section{Results and discussion}

\subsection{Chemical characterization}

\subsubsection{Phenolic compounds}

The phenolic profile, chromatographic characteristics (Rt, $\lambda$ max, and mass spectral data), tentative identifications, and quantification of jabuticaba epicarp is shown in Table 1 . The purified hydroethanolic extract presented sixteen phenolic compounds, being fourteen non-anthocyanins (thirteen ellagitannins and one quercetin derivate) and two anthocyanin compounds. According to the mass spectral data presented in the Table 1, peaks $\mathbf{1}$ and $\mathbf{2}$ showed the same pseudomolecular $\left([\mathrm{M}-\mathrm{H}]^{-}\right.$at $m / z$ 783) and released two $\mathrm{MS}^{2}$ fragment at $m / z 481$ $(-302 \mathrm{u}$, loss of an HHDP unit) and $m / z 301$ (ellagic acid) presenting a further loss a hexose $(-180 \mathrm{u})$. Plaza et al. (2016) and Morales et al. (2016) also detected a similar fragmentation behavior in aqueous extract from M. jaboticaba epicarp from the Southeast part of Brazil and in methanolic extract of jabuticaba pomace (epicarp, seed and residual pulp) obtained from licour and juice processing of Myrciaria cauliflora Mart, obtained from the Central Region of Brazil, being these compounds tentatively identified as bis-HHDP-glucose isomers. Peaks $\mathbf{3}$ and $4\left([\mathrm{M}-\mathrm{H}]^{-}\right.$at $\left.\mathrm{m} / \mathrm{z} 951\right)$ also presented compound isomers with two $\mathrm{MS}^{2}$ fragment at $m / z 907$ and $m / z 783$, these compounds were associated to trigalloyl-HHDP-glucose isomers. These identifications were performed taking into account previous reported studies using an acidified methanolic extract obtained from epicarp of Myrciaria trunciflora (a different jabuticaba species) from the southern region of Brazil (Quatrin et al., 2019) and an acetonic extract from the edible part (epicarp and pulp) of Araça (Psidium guineense Sw.), from the Amazon Region and also belonging to the Myrtaceae family (Gordon, Jungfer, Da Silva, Maia, \& Marx, 2011). Peaks 5 and $7\left([\mathrm{M}-\mathrm{H}]^{-}\right.$at $\mathrm{m} / \mathrm{z}$ 935) had the same $\mathrm{MS}^{2}$ fragments at $\mathrm{m} / \mathrm{z} 917(-18 \mathrm{u}$, loss of a water molecule), $m / z 783$ ( $-152 \mathrm{u}$, loss of a galloyl group), $m / z 633(-302 \mathrm{u}$, loss of an HHDP group) and $m / z 301$ ( -332 u galloyl-glucose moieties); thus the identification of these compounds was galloyl-bis-HHDP-glucose isomers, being also confirmed with literature data to $M$. jaboticaba (Plaza et al., 2016). Peak $6\left([\mathrm{M}-\mathrm{H}]^{-}\right.$at $m / z$ 633) released a $\mathrm{MS}^{2}$ fragmentation patter at $m / z 481$ ( $-152 \mathrm{u}$, loss of a galloyl moiety), $\mathrm{m} / \mathrm{z}$ $463(-170 \mathrm{u}$, loss of a gallic acid) and $m / z 301(-162 \mathrm{u}$, loss of a glucosyl residue), being assigned as a galloyl-HHDP-glucose. This compound was also previously described by Morales et al. (2016) in the methanolic extract obtained from jabuticaba (M. cauliflora) pomace. The same pseudomolecular ion at $[\mathrm{M}-\mathrm{H}]^{-}$at $m / z$ 785, and $\mathrm{MS}^{2}$ fragmentation patter at $m / z 633$ and 483, revealing two successive losses of galloyl moieties $(-152 \mathrm{u}$ ) and $m / z 301$ corresponding to ellagic acid ( $-162 \mathrm{u}$ loss of hexose residue), were found for peaks 8 and 9, and according with data reported in literature, these compounds were tentative identified as digalloyl-HHDP-glucose isomers (Morales et al., 2016; Wu, Long, \& Kennelly, 2013). Peaks 10 and $11\left([\mathrm{M}-\mathrm{H}]^{-}\right.$ at $m / z 933$ ) presented the same $\mathrm{MS}^{2}$ fragment ions at $m / z 915,633,451$ (loss of a trigalloyl unit) and 301, and were tentatively assigned to castalagin/vescalagin isomers, due the similar characteristic spectral data found from other Brazilian Myrtaceae fruits (Gordon et al., 2011); however to the best of our knowledge this was the first time this compound was identified in M. jaboticaba. Peak $12\left([\mathrm{M}-\mathrm{H}]^{-}\right.$at $m / z$ 937) presented four $\mathrm{MS}^{2}$ fragments at $m / z 767,637,467$ and 301, being coherent with a trigalloyl-HHDP-glucose, already reported in M. jaboticaba epicarp aqueous extract (Plaza et al., 2016; Wu, Dastmalchi, Long, \& Kennelly, 2012). Peak $13\left([\mathrm{M}-\mathrm{H}]^{-}\right.$at $m / z$ 939) revealed a $\mathrm{MS}^{2}$ fragmentation pattern at $m / z 787,769$ and 301 tentatively identified as pentagalloy glucose (Plaza et al., 2016).

Peak $14\left([\mathrm{M}-\mathrm{H}]^{-}\right.$at $\left.m / z 447\right)$ was the only flavonoid present in the extract and was tentatively identified as quercetin-3-O-rhamnoside (quercitrin), taking into account previous findings reported for jabuticaba residues (Morales et al., 2016; Plaza et al., 2016).

Concerning, the total phenolic non-anthocyanin content $(7.48 \pm 0.03 \mathrm{mg} / \mathrm{g}$ and $3.59 \pm 0.01 \mathrm{mg} / \mathrm{g}$ of ethanolic extract and dryer jabuticaba epicarp, respectively), hydrolyzed tannins (ellagitannins) were the main group of molecules present ( $\sim 98 \%$ of the TFC non-anthocyanin), this is in accordance with data reported by other authors (Morales et al., 2016; Plaza et al., 2016). This group of compounds has been largely studied due to their great bioactive proprieties, such as antimicrobial, anti-proliferative and anti-inflammatory activity (Lipińska, Klewicka, \& Sójka, 2014). Trigalloyl-HHPD-glucose was the major compound $(1.408 \pm 0.003 \mathrm{mg} / \mathrm{g} \mathrm{dw})$, followed by pentagalloyl glucose $(0.51 \pm 0.02 \mathrm{mg} / \mathrm{g} \mathrm{dw})$. These values were higher than those found by Plaza et al. (2016). However, the amount of quercetin-3-Orhamnoside (quercitrin) detected in our work was relatively lower than those reported by these authors $(0.051 \mathrm{mg} / \mathrm{g} \mathrm{dw}$ against $0.61 \mathrm{mg} / 100 \mathrm{~g}$ $\mathrm{dw}$, respectively). These differences could be due to several factors, such as a different kind of extraction method and solvents used (Naczk \& Shahidi, 2004), as well as different stages of maturation (Betta et al., 2018; Oliveira et al., 2019).

Jabuticaba also displayed two anthocyanins as presented in Table 1. Peak $15\left([\mathrm{M}+\mathrm{H}]^{+}\right.$at $\left.m / z 463\right)$ depict a unique $\mathrm{MS}^{2}$ fragment at $m / z$ 303 , corresponding to a delphinidin, bearing the loss of a hexose moiety $(-162 \mathrm{u}$ ), being assigned as delphinidin-3-O-glucoside (D3G) (de Neves et al., 2018; Morales et al., 2016; Plaza et al., 2016). Peak $16\left([\mathrm{M}+\mathrm{H}]^{+}\right.$ at $m / z 449$ ) was identified as cyanidin-3-O-glucoside (C3G), in comparison to the chromatographic and MS characteristics to the standard compound, as also with previous reported literature (de Neves et al., 2018; Morales et al., 2016; Plaza et al., 2016). The main anthocyanin present in the epicarp was C3G $(19.45 \pm 0.07 \mathrm{mg} / \mathrm{g} \mathrm{dw})$, being the total anthocyanin content found in the jabuticaba epicarp of $50.1 \pm 0.1 \mathrm{mg} / \mathrm{g}$ of extract and $24.54 \pm 0.05 \mathrm{mg} / \mathrm{g} \mathrm{dw}$. The proportion between C3G and D3G was similar with those found by Inada et al. (2015) in an acidified methanolic extract from M. jaboticaba epicarp, 12.61 and $2.69 \mathrm{mg} / \mathrm{g} \mathrm{dw}$, respectively. However, these results differ in terms of proportion and quantity with those reported by Plaza et al. (2016) for M. jaboticaba epicarp extract obtained by pressurized hot water, where the amount of C3G was about eight times higher than D3G, 28.66 and $35.63 \mathrm{mg} / \mathrm{g} \mathrm{dw}$, respectively. In these studies, the authors used different solvents and extraction methods, which can influence over the result obtained in each work (Naczk \& Shahidi, 2004). Moreover, these differences may also be caused by the different ripening stages and cultivation conditions of $M$. jaboticaba (Betta et al., 2018; Oliveira et al., 2019). 


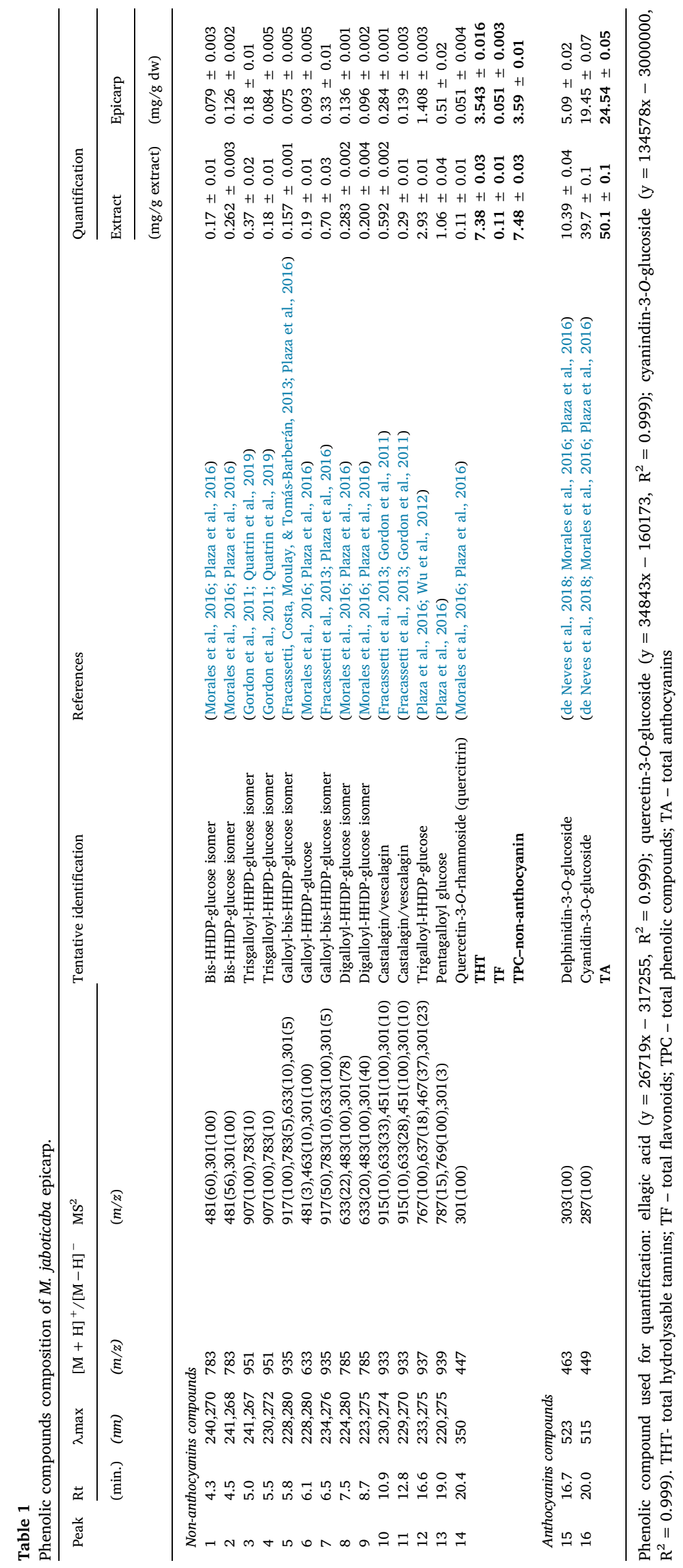


Table 2

Organic acids and tocopherols composition of $M$. jaboticaba epicarp.

\begin{tabular}{ll}
\hline ORGANIC ACIDS & $m g / 100 g d w$ \\
\hline Oxalic acid & $0.481 \pm 0.009$ \\
Quinic acid & $0.554 \pm 0.002$ \\
Malic acid & $1.66 \pm 0.01$ \\
Shikimic acid & $0.125 \pm 0.008$ \\
Citric acid & $18.8 \pm 0.1$ \\
Fumaric acid & $\operatorname{tr}$ \\
Total organic acids & $21.67 \pm 0.09$ \\
TOCOPHEROLS & $m g / 100 g d w$ \\
\hline$\alpha$-tocopherol & $0.301 \pm 0.002$ \\
$\beta$-tocopherol & $0.194 \pm 0.005$ \\
$\gamma$-tocopherol & $0.56 \pm 0.01$ \\
$\delta$-tocopherol & $0.66 \pm 0.02$ \\
Total tocopherols & $1.71 \pm 0.03$ \\
\hline
\end{tabular}

tr- traces.

In comparison to other brazilian fruit residues, the total content of anthocyanins in jabuticaba epicarp extract is relatively higher than those found in extract obtained from grape skin and juçara residue (7.9 and $11.54 \mu \mathrm{g} / \mathrm{g}$ of extract, respectively) (Garcia et al., 2019; Peixoto et al., 2018). Interestingly, the major anthocyanin present in $M$. jaboticaba epicarp, C3G, has presented positive effects against lipolysaccharides (LPS)-induced inflammation on human rheumatoid fibroblast (Sun \& Li, 2018).

\subsubsection{Organic acids}

The composition in organic acids of jabuticaba epicarp is presented in Table 2. Six organic acids were detected in this by-product, with a clear predominance of citric acid $(18.8 \pm 0.1 \mathrm{mg} / 100 \mathrm{~g} \mathrm{dw})$, but it also presented malic acid in a lower concentration, followed by quinic and oxalic acids $(1.66 \pm 0.01,0.554 \pm 0.002$, and $0.481 \pm 0.009 \mathrm{mg}$ / $100 \mathrm{~g} \mathrm{dw}$, respectively). Shikimic $(0.125 \pm 0.008 \mathrm{mg} / 100 \mathrm{~g} \mathrm{dw})$ and fumaric acids were the least abundant organic acids found in the sample, with the latter only detected in a residual quantity. The results obtained highlight the importance of recovering this kind of residues given their high concentration in compounds such as those reported. Indeed, citric acid is well used in several industrial fields for different purposes, being mainly used in food processing, where it can be applied as an acidifying or preserving agent or even to enhance foodstuff flavour and aroma, but it can also find application in the pharmaceutical industry as an antioxidant for vitamins, a $\mathrm{pH}$ corrector and other functions (Ciriminna, Meneguzzo, Delisi, \& Pagliaro, 2017). The results found herein are similar to those described by Morales et al. (2016) in a study that involved jabuticaba pomace generated from juice and wine processing, mainly composed of epicarp, pulp, and seeds.

\subsubsection{Tocopherols}

Table 2 presents the tocopherols profile of jabuticaba epicarp. The isoforms $\alpha, \beta, \gamma$, and $\delta$-tocopherol were identified in this sample, with $\delta$ and $\gamma$-tocopherol being the major isomers detected $(0.66 \pm 0.02$ and $0.56 \pm 0.01 \mathrm{mg} / 100 \mathrm{~g} \mathrm{dw}$, respectively). To the best of our knowledge, this is the first report regarding tocopherols composition in this part of the $M$. jaboticaba fruit. Morales et al. (2016) determined the total tocopherols content of jabuticaba pomace and the results reported were significantly higher than those obtained in the present study (3.3 and $3.2 \mathrm{mg} / 100 \mathrm{~g}$ of dry pomace of wine and juice, respectively), which can be justified by the presence of pulp and seeds in the pomaces. Comparing the tocopherols concentration of jabuticaba epicarp with those found in other matrices, such as grape skin $(\sim 0.014 \mathrm{mg} / \mathrm{g} \mathrm{dw})$ or grape pomace $(\sim 0.0147 \mathrm{mg} / \mathrm{g} \mathrm{dw})$, this by-product presented greater amounts (Gülcü et al., 2018). The benefits of tocopherols consumption, also known as lipid-soluble vitamin $\mathrm{E}$, are widely recognized and
Table 3

Cell-based antioxidant activity of $M$. jaboticaba epicarp.

\begin{tabular}{|c|c|c|c|}
\hline & \multicolumn{2}{|c|}{ OxHLIA (IC 50 values; $\mu \mathrm{g} / \mathrm{ml}$ ) } & \multirow{2}{*}{$\begin{array}{l}\text { TBARS (IC } 50 \text { values; } \mu \mathrm{g} / \\
-\mathrm{ml})\end{array}$} \\
\hline & $\Delta \mathrm{t}_{120 \mathrm{~min}}$ & $\Delta \mathrm{t}_{180 \min }$ & \\
\hline $\begin{array}{c}\text { M. jaboticaba } \\
\text { epicarp }\end{array}$ & $0.82 \pm 0.03$ & $1.2 \pm 0.1$ & $2.07 \pm 0.03$ \\
\hline Trolox & $41.1 \pm 0.8$ & $63 \pm 1$ & $5.8 \pm 0.6$ \\
\hline
\end{tabular}

described, being that this essential micronutrient is associated with the prevention of several diseases due its anti-inflammatory and antioxidant properties (Jiang, Christien, Shigenaga, \& Ames, 2001).

\subsection{Bioactive proprieties of jabuticaba epicarp extract}

\subsubsection{Cell-based antioxidant activity}

The hydroethanolic extract prepared from jabuticaba epicarp was evaluated in terms of its ability to prevent lipid peroxidation of porcine brain tissues and haemolysis of sheep blood cells. The results are presented in the Table 3. Regarding the TBARS assay, jabuticaba epicarp extract showed a great antioxidant activity, presenting an $\mathrm{IC}_{50}$ value of $2.07 \pm 0.03 \mu \mathrm{g} / \mathrm{ml}$, which represents a higher activity than Trolox $(5.8 \pm 0.6 \mu \mathrm{g} / \mathrm{ml})$, the positive control. In fact, previous studies carried out with jabuticaba epicarp extracts assessing its antioxidant activity in Bologna-type sausages, revealed that the presence of this extract led to the formation of lower amounts of TBARS after 35 days of storage (Almeida et al., 2015). Similar results were obtained by Baldin et al. (2018), which incorporated microencapsulated extracts from jabuticaba residue (epicarp and seeds) in mortadella sausages to evaluate their capacity to inhibit lipid peroxidation with 56 days of storage. In the referred studies, the authors suggest that the antioxidant properties showed by the extracts are mainly ascribed to their anthocyanin composition (Almeida et al., 2015; Baldin et al., 2016). With this by-product, the antioxidant activity achieved is higher than those obtained through the application of residues from grape and juçara in similar food products (Garcia et al., 2019; Peixoto et al., 2018).

In the OxHLIA assay, the extract concentrations needed to protect half of the erythrocyte population from the haemolytic action caused by an oxidative agent for $120 \mathrm{~min}(0.82 \pm 0.03 \mu \mathrm{g} / \mathrm{ml})$ and $180 \mathrm{~min}$ $(1.2 \pm 0.1 \mu \mathrm{g} / \mathrm{ml})$ were more than 50 times lower than those required for the artificial antioxidant, Trolox (41.1 and $63 \mu \mathrm{g} / \mathrm{ml}$, for 120 and $180 \mathrm{~min}$, respectively). Once again, these results highlight the great antioxidant activity of the extract and corroborate the huge potential to be applied for antioxidant purposes, for instance, in food industry. There are several methods to evaluate the antioxidant capacity of an extract, but most of them are chemical methods based on the scavenging of free radicals, notwithstanding, the OxHLIA method is cell-based and has the main advantage of inducing erythrocyte haemolysis by two ways in aqueous systems: 1) by the action of hydrophilic radicals generated from the thermal decomposition of APPH (2,20-azobis(2methyl-propionamidine) that attack the erythrocytes membrane; and 2) by lipophilic radicals generated by the oxidation of the erythrocyte membrane; thus promoting similar conditions to in vivo systems (Prieto \& Vásquez, 2014). In an in vivo study conducted by Plaza et al. (2016) with volunteers, the consumption of jabuticaba epicarp powder strengthened the serum antioxidant capacity against peroxyl radicals, which can be mainly explained by its composition of phenolic compounds, namely anthocyanins and ellagitannins (Plaza et al., 2016; Zhao et al., 2019). In comparison to other residues, the jabuticaba epicarp extract was notoriously more efficient on retarding the erythrocytes haemolysis than juçara residues extract $\left(\mathrm{IC}_{50(120 \mathrm{~min})}=107 \mu \mathrm{g} / \mathrm{ml}\right)$ (Garcia et al., 2019).

\subsubsection{Anti-inflammatory activity}

The anti-inflammatory potential of the jabuticaba epicarp extract 
Table 4

Anti-inflammatory and cytotoxic activity of $M$. jaboticaba epicarp.

\begin{tabular}{|c|c|c|}
\hline Anti-inflammatory activity $\mathrm{IC}_{50}(\mu \mathrm{g} / \mathrm{ml})$ & $\begin{array}{l}\text { M. jaboticaba } \\
\text { epicarp }\end{array}$ & Dexamethasone \\
\hline RAW 264.7 & $299 \pm 13$ & $16 \pm 1$ \\
\hline Anti-proliferative activity $\mathrm{GI}_{50}(\mu \mathrm{g} / \mathrm{ml})$ & & Ellipticine \\
\hline MCF-7 (breast carcinoma) & $300 \pm 17$ & $0.91 \pm 0.04$ \\
\hline $\begin{array}{l}\text { NCI-H460 (non-small cell lung } \\
\text { carcinoma) }\end{array}$ & $>400$ & $1.0 \pm 0.1$ \\
\hline HeLa (cervical carcinoma) & $278 \pm 7$ & $1.91 \pm 0.06$ \\
\hline HepG2 (hepatocellular carcinoma) & $258 \pm 5$ & $1.1 \pm 0.2$ \\
\hline \multicolumn{3}{|l|}{ Hepatotoxicity $\mathrm{GI}_{50}(\mu \mathrm{g} / \mathrm{ml})$} \\
\hline PLP2 & $>400$ & $3.2 \pm 0.7$ \\
\hline
\end{tabular}

was evaluated and the results are presented in Table 4. The extract exhibited anti-inflammatory activity, inhibiting the growth of RAW 264.7 mouse macrophages in a concentration of $299 \pm 13 \mu \mathrm{g} / \mathrm{ml}$, which, despite being higher than the one exhibited by the positive control, Dexamethasone (16 $\pm 1 \mu \mathrm{g} / \mathrm{ml}$ ), was obtained with a by-product extract, justifying its consideration as a natural alternative. In a previous study, jabuticaba epicarp also presented anti-inflammatory activity for chronic obstructive pulmonary disease (Zhao et al., 2019), which has been associated with the presence of certain phytochemicals. For instance, the jabuticaba tree and its whole fruit are reported as sources of jaboticabin (methyl 2-[(3,4-dihydroxybenzoyloxy)-4,6-dihydroxyphenyl] acetate), being that this compound mostly present in the epicarp (Zhao et al., 2019). This molecule was identified for the first time in jabuticaba fruits in 2006 (Adachi et al., 2006) and belongs to the depsides class, which are polyphenols with two or more aromatic rings linked by an ester bond, known by their bioactive properties, such as antibiotic, anti-HIV, and antiproliferative activity.

\subsubsection{Anti-proliferate activity and hepatotoxicity}

Cancer is one of the diseases that causes the greatest number of deaths worldwide. Phytochemicals and functional foods have been reported as crucial agents in preventing the development of these abnormal cells (Kotecha, Takami, \& Espinoza, 2016; Li, Wang, Luo, Zhao, \& Chen, 2017). The potential of jabuticaba epicarp in inhibiting tumor cell growth was evaluated in four different tumor cell lines and the results obtained are presented in Table 4 . The extract revealed antiproliferate activity in all tumor cells assessed in concentrations ranging from $258 \pm 5$ (in HepG2) to $300 \pm 17$ (in MCF-7) $\mu \mathrm{g} / \mathrm{ml}$, except for NCI-H460 $\left(\mathrm{GI}_{50}\right.$ value $\left.>400 \mu \mathrm{g} / \mathrm{ml}\right)$. On the other hand, it did not reveal toxicity for PLP2, a non-tumor liver cell primary culture, which corroborates the possibility of its application in food matrices without risks of toxicity. The anti-proliferative activity of jabuticaba epicarp against non-small lung cancer cells was previously described by LeiteLegatti et al. (2012), in a study where the authors found $\mathrm{GI}_{50}$ values of 28 and $209 \mu \mathrm{g} / \mathrm{ml}$ for non-polar (extraction with dichloromethane) and polar (extraction with $80 \%$ ethanol) extracts, respectively. In addition, jabuticaba epicarp also showed inhibitory activity in the tumour cells of glioma (U251), melanoma (UACC-62), kidney (786-0), leukemia (k562), and prostate (Leite-Legatti et al., 2012). The chemoprotective properties revealed by these anthocyanin rich matrices against several types of cancer cells have been previously reported (Li et al., 2017).

\subsubsection{Antimicrobial activity}

The results of the antibacterial activity of the tested ethanolic extract are presented in Table 5. $M$. jaboticaba epicarp extract was active against all the tested microorganisms, inhibiting their growth at concentrations of 10 and $20 \mathrm{mg} / \mathrm{ml}$ (MIC values), in the case of Gram-positive and Gram-negative bacteria, respectively. Nevertheless, it did not present bactericidal properties at the studied concentration $(20 \mathrm{mg} / \mathrm{ml})$. In $M$. morganii, the MIC value presented by the extract was the same as the one presented by the positive control Ampicillin, and in P. aeruginosa, the extract presented even higher activity than this antibiotic. The potential of growth inhibition against E. coli, S. aureus, and L. monocytogenes found in this study is in agreement with the results obtained by Machado et al. (2018). In what concerns the addition of jabuticaba epicarp extract to food matrices, no positive nor negative effects were verified in different types of sausages in terms of microbial characteristic (aerobic bacteria count) of the products along with storage time (Almeida et al., 2015; Baldin et al., 2016).

\section{Conclusion}

With this study, it was possible to characterize a food industry byproduct, jabuticaba epicarp, and contribute to its valorisation as source of compounds with great interest for different industries, such as food or pharmaceutical, among others. To our best knowledge, this is the first study describing the tocopherol profile of $M$. jaboticaba epicarp. In addition, the results of the present work showed that jabutibaca epicarp is rich in anthocyanins and ellagitannins, which were considered the main responsible compounds for the great bioactive properties presented by its extract.

\section{Declaration of Competing Interest}

The authors declare that they have no known competing financial interests or personal relationships that could have appeared to influence the work reported in this paper.

Table 5

Antibacterial activity of $M$. jaboticaba epicarp.

\begin{tabular}{|c|c|c|c|c|c|c|c|c|}
\hline & \multicolumn{2}{|c|}{ M. jaboticaba epicarp } & \multicolumn{2}{|c|}{ Ampicillin $(20 \mathrm{mg} / \mathrm{ml})$} & \multicolumn{2}{|c|}{ Imipenem (1 mg/ml) } & \multicolumn{2}{|c|}{ Vancomycin $(1 \mathrm{mg} / \mathrm{ml})$} \\
\hline & MIC & MBC & MIC & MBC & MIC & MBC & MIC & MBC \\
\hline \multicolumn{9}{|l|}{ Gram-negative bacteria } \\
\hline Escherichia coli & 20 & $>20$ & $<0.15$ & $<0.15$ & $<0.0078$ & $<0.0078$ & nt & nt \\
\hline Klebsiella pneumoniae & 20 & $>20$ & 10 & 20 & $<0.0078$ & $<0.0078$ & nt & $\mathrm{nt}$ \\
\hline Morganella morganii & 20 & $>20$ & 20 & $>20$ & $<0.0078$ & $<0.0078$ & nt & nt \\
\hline Proteus mirabilis & 20 & $>20$ & $<0.15$ & $<0.15$ & $<0.0078$ & $<0.0078$ & nt & $\mathrm{nt}$ \\
\hline Pseudomonas aeruginosa & 20 & $>20$ & $>20$ & $>20$ & 0.5 & 1 & nt & $\mathrm{nt}$ \\
\hline \multicolumn{9}{|l|}{ Gram-positive bacteria } \\
\hline Enterococcus faecalis & 10 & $>20$ & $<0.15$ & $<0.15$ & nt & nt & $<0.0078$ & $<0.0078$ \\
\hline Listeria monocytogenes & 10 & $>20$ & $<0.15$ & $<0.15$ & $<0.0078$ & $<0.0078$ & nt & nt \\
\hline MRSA & 10 & $>20$ & $<0.15$ & $<0.15$ & $\mathrm{nt}$ & nt & 0.25 & 0.5 \\
\hline
\end{tabular}

MRSA - Methicillin resistant Staphylococcus aureus; MIC - minimal inhibitory concentration; MBC - minimal bactericidal concentration; nt - not tested. 


\section{Acknowledgements}

The authors are grateful to the Foundation for Science and Technology (FCT, Portugal) and FEDER under Programme PT2020 for financial support to CIMO (UID/AGR/00690/2019); national funding by FCT, P.I., through the institutional scientific employment programcontract for M.I. Dias, L. Barros, and R.C. Calhelha contracts; C. Pereira contract though the celebration of program-contract foreseen in No. 4, 5 and 6 of article $23^{\circ}$ of Decree-Law No. 57/2016, of 29th August, amended by Law No. 57/2017, of 19th July; and B. Albuquerque (SFRH/BD/136370/2018) PhD grant; to FEDER-Interreg EspañaPortugal programme for financial support through the project 0377_Iberphenol_6_E; the European Regional Development Fund (ERDF) through the Regional Operational Program North 2020, within the scope of Project NORTE-01-0145-FEDER-023289: DeCodE and project Mobilizador Norte-01-0247-FEDER-024479: ValorNatural ${ }^{\circledR}$. The authors thank Dra. Cyanthia J. Kunigk (Instituto Mauá de Tecnologia, Brazil) for her collaboration.

\section{References}

Adachi, S., Weinstein, I. B., Gil, R. R., Wallace, A. M., Reynertson, K. A., Kennelly, E. J., ... D’Armiento, J. (2006). Bioactive depsides and anthocyanins from jaboticaba (Myrciaria cauliflora). Journal of Natural Products, 69(8), 1228-1230. https://doi.org/ 10.1021/np0600999.

Almeida, P. L., Lima, S. N., Costa, L. L., de Oliveira, C. C., Damasceno, K. A., dos Santos, B. A., \& Campagnol, P. C. B. (2015). Effect of jabuticaba peel extract on lipid oxidation, microbial stability and sensory properties of Bologna-type sausages during refrigerated storage. Meat Science, 110, 9-14. https://doi.org/10.1016/J.MEATSCI. 2015.06.012.

Baldin, J. C., Michelin, E. C., Polizer, Y. J., Rodrigues, I., Godoy, S. H. S., Fregonesi, R. P., ... Trindade, M. A. (2016). Microencapsulated jabuticaba (Myrciaria cauliflora) extract added to fresh sausage as natural dye with antioxidant and antimicrobial activity. Meat Science, 118, 15-21. https://doi.org/10.1016/j.meatsci.2016.03.016.

Baldin, J. C., Munekata, P. E. S., Michelin, E. C., Polizer, Y. J., Silva, P. M., Canan, T. M., . Trindade, M. A. (2018). Effect of microencapsulated Jabuticaba (Myrciaria cauliflora) extract on quality and storage stability of mortadella sausage. Food Research International, 108, 551-557. https://doi.org/10.1016/J.FOODRES.2018.03.076.

Barros, L., Pereira, E., Calhelha, R. C., Dueñas, M., Carvalho, A. M., Santos-Buelga, C., \& Ferreira, I. C. F. R. (2013). Bioactivity and chemical characterization in hydrophilic and lipophilic compounds of Chenopodium ambrosioides L. Journal of Functional Foods, 5(4), 1732-1740. https://doi.org/10.1016/j.jff.2013.07.019.

Bessada, S. M. F., Barreira, J. C. M., Barros, L., Ferreira, I. C. F. R., \& Oliveira, M. B. P. P. (2016). Phenolic profile and antioxidant activity of Coleostephus myconis (L.) Rchb.f.: An underexploited and highly disseminated species. Industrial Crops and Products, 89, 45-51. https://doi.org/10.1016/J.INDCROP.2016.04.065.

Betta, F. Della, Nehring, P., Seraglio, S. K. T., Schulz, M., Valese, A. C., Daguer, H., ... Costa, A. C. O. (2018). Phenolic compounds determined by LC-MS/MS and in vitro antioxidant capacity of Brazilian fruits in two edible ripening stages. Plant Foods for Human Nutrition, 73(4), 302-307. https://doi.org/10.1007/s11130-018-0690-1.

Ciriminna, R., Meneguzzo, F., Delisi, R., \& Pagliaro, M. (2017). Citric acid: Emerging applications of key biotechnology industrial product. Chemistry Central Journal, 11(1), 1-9. https://doi.org/10.1186/s13065-017-0251-y.

Corrêa, R. C. G., De Souza, A. H. P., Calhelha, R. C., Barros, L., Glamoclija, J., Sokovic, M., ... Ferreira, I. C. F. R. (2015). Bioactive formulations prepared from fruiting bodies and submerged culture mycelia of the Brazilian edible mushroom Pleurotus ostreatoroseus Singer. Food and Function, 6(7), 2155-2164. https://doi.org/10.1039/ c5fo00465a.

de Neves, N. A., Stringheta, P. C., Gómez-Alonso, S., \& Hermosín-Gutiérrez, I. (2018). Flavonols and ellagic acid derivatives in peels of different species of jabuticaba (Plinia spp.) identified by HPLC-DAD-ESI/MSn. Food Chemistry, 252, 61-71. https://doi.org/ 10.1016/J.FOODCHEM.2018.01.078.

Donado-Pestana, C. M., Moura, M. H. C., de Araujo, R. L., de Lima Santiago, G., de Moraes Barros, H. R., \& Genovese, M. I. (2018). Polyphenols from Brazilian native Myrtaceae fruits and their potential health benefits against obesity and its associated complications. Current Opinion in Food Science, 19, 42-49. https://doi.org/10.1016/J.COFS. 2018.01.001.

Fracassetti, D., Costa, C., Moulay, L., \& Tomás-Barberán, F. A. (2013). Ellagic acid derivatives, ellagitannins, proanthocyanidins and other phenolics, vitamin $\mathrm{C}$ and antioxidant capacity of two powder products from camu-camu fruit (Myrciaria dubia). Food Chemistry, 139(1-4), 578-588. https://doi.org/10.1016/j.foodchem.2013.01. 121.

Garcia, J. A. A., Corrêa, R. C. G., Barros, L., Pereira, C., Abreu, R. M. V., Alves, M. J., ... Ferreira, I. C. F. R. (2019). Chemical composition and biological activities of Juçara (Euterpe edulis Martius) fruit by-products, a promising underexploited source of highadded value compounds. Journal of Functional Foods, 55, 325-332. https://doi.org/ 10.1016/J.JFF.2019.02.037.

Gonçalves, G. A., Soares, A. A., Correa, R. C. G., Barros, L., Haminiuk, C. W. I., Peralta, R. M., ... Bracht, A. (2017). Merlot grape pomace hydroalcoholic extract improves the oxidative and inflammatory states of rats with adjuvant-induced arthritis. Journal of Functional Foods, 33, 408-418. https://doi.org/10.1016/J.JFF.2017.04.009.

Gordon, A., Jungfer, E., Da Silva, B. A., Maia, J. G. S., \& Marx, F. (2011). Phenolic constituents and antioxidant capacity of four underutilized fruits from the amazon region. Journal of Agricultural and Food Chemistry, 59(14), 7688-7699. https://doi. org/10.1021/jf201039r.

Gülcü, M., Uslu, N., Özcan, M. M., Banjanin, T., Özcan, M. M., Geçgel, Ü., ... Ceylan, D. A. (2018). The investigation of bioactive compounds of wine, grape juice and boiled grape juice wastes. Journal of Food Processing and Preservation, 43(1), e13850. https:// doi.org/10.1111/jfpp.13850.

Inada, K. O. P., Oliveira, A. A., Revorêdo, T. B., Martins, A. B. N., Lacerda, E. C. Q., Freire, A. S., ... Monteiro, M. C. (2015). Screening of the chemical composition and occurring antioxidants in jabuticaba (Myrciaria jaboticaba) and jussara (Euterpe edulis) fruits and their fractions. Journal of Functional Foods, 17, 422-433. https://doi.org/10.1016/J. JFF.2015.06.002.

Jiang, Q., Christien, S., Shigenaga, M. K., \& Ames, B. N. (2001). $\gamma$-Tocopherol, the major form of vitamin $\mathrm{E}$ in the US diet, deserves more attention. American Journal of Clinical Nutrition, 74(6), 714-722. https://doi.org/10.1093/ajcn/74.6.714.

Kotecha, R., Takami, A., \& Espinoza, J. L. (2016). Dietary phytochemicals and cancer chemoprevention: A review of the clinical evidence. Oncotarget, 7(32), https://doi. org/10.18632/oncotarget.9593.

Leite-Legatti, A. V., Batista, Â. G., Dragano, N. R. V., Marques, A. C., Malta, L. G., Riccio, M. F., ... Maróstica, M. R. (2012). Jaboticaba peel: Antioxidant compounds, antiproliferative and antimutagenic activities. Food Research International, 49(1), 596-603. https://doi.org/10.1016/J.FOODRES.2012.07.044.

Li, D., Wang, P., Luo, Y., Zhao, M., \& Chen, F. (2017). Health benefits of anthocyanins and molecular mechanisms: Update from recent decade. Critical Reviews in Food Science and Nutrition, 57(8), 1729-1741. https://doi.org/10.1080/10408398.2015.1030064.

Lipińska, L., Klewicka, E., \& Sójka, M. (2014). Structure, occurrence and biological activity of ellagitannins: A general review. Acta Scientiarum Polonorum Technologiia Alimentaria, 13(3), 289-299. https://doi.org/10.17306/J.AFS.2014.3.7.

Lockowandt, L., Pinela, J., Roriz, C. L., Pereira, C., Abreu, R. M. V., Calhelha, R. C., ... Ferreira, I. C. F. R. (2019). Chemical features and bioactivities of cornflower (Centaurea cyanus L.) capitula: The blue flowers and the unexplored non-edible part. Industrial Crops and Products, 128, 496-503. https://doi.org/10.1016/j.indcrop.2018. 11.059.

Machado, G. H. A., Caetano, A. A., Corrêa, A. D., de Oliveira, F. C., de Carvalho, T. C. L., Batista, L. R., \& Marques, T. R. (2018). Jabuticaba skin extracts: Phenolic compounds and antibacterial activity. Brazilian Journal of Food Technology, 21, 1-11. https://doi. org/10.1590/1981-6723.10817.

Marquetti, C., Batista, T., Fabiana, K., Kaipers, C., Böger, B. R., Tonial, I. B., ... Vieira, N. (2018). Jaboticaba skin flour: Analysis and sustainable alternative source to incorporate bioactive compounds and increase the nutritional value of cookies. Food Science and Technology, 2061(4), 629-638. https://doi.org/10.1590/fst.06717.

Morales, P., Barros, L., Dias, M. I., Santos-Buelga, C., Ferreira, I. C. F. R., Ramirez Asquieri, E., \& Berrios, J. D. J. (2016). Non-fermented and fermented jabuticaba (Myrciaria cauliflora Mart.) pomaces as valuable sources of functional ingredients. Food Chemistry, 208, 220-227. https://doi.org/10.1016/J.FOODCHEM.2016.04.011.

Naczk, M., \& Shahidi, F. (2004). Extraction and analysis of phenolics in food. Journal of Chromatography A, 1054(1-2), 95-111. https://doi.org/10.1016/J.CHROMA.2004. 08.059.

Neri-Numa, I. A., Soriano Sancho, R. A., Pereira, A. P. A., \& Pastore, G. M. (2018). Small Brazilian wild fruits: Nutrients, bioactive compounds, health-promotion properties and commercial interest. Food Research International, 103, 345-360. https://doi.org/ 10.1016/j.foodres.2017.10.053.

Oliveira, G. P., Angelotti-Mendonça, J., Tanaka, F. A. O., da Silva, S. R., \& Scarpare Filho, J. A. (2019). Origin and development of reproductive buds in jabuticaba cv. Sabará (Plinia jaboticaba Vell). Scientia Horticulturae, 249, 432-438. https://doi.org/10. 1016/J.SCIENTA.2019.02.020.

Peixoto, C. M., Dias, M. I., Alves, M. J., Calhelha, R. C., Barros, L., Pinho, S. P., \& Ferreira, I. C. F. R. (2018). Grape pomace as a source of phenolic compounds and diverse bioactive properties. Food Chemistry, 253, 132-138. https://doi.org/10.1016/J. FOODCHEM.2018.01.163.

Pires, T. C. S. P., Dias, M. I., Barros, L., Calhelha, R. C., Alves, M. J., Santos-Buelga, C., \& Ferreira, I. C. F. R. (2018). Phenolic compounds profile, nutritional compounds and bioactive properties of Lycium barbarum L.: A comparative study with stems and fruits. Industrial Crops and Products, 122, 574-581. https://doi.org/10.1016/j. indcrop.2018.06.046.

Plaza, M., Batista, Â. G., Cazarin, C. B. B., Sandahl, M., Turner, C., Östman, E., \& Maróstica Júnior, M. R. (2016). Characterization of antioxidant polyphenols from Myrciaria jaboticaba peel and their effects on glucose metabolism and antioxidant status: A pilot clinical study. Food Chemistry, 211, 185-197. https://doi.org/10.1016/ J.FOODCHEM.2016.04.142.

Prieto, M. A., \& Vásquez, J. A. (2014). A time-dose model to quantify the antioxidant responses of the oxidative hemolysis inhibition assay (OxHLIA) and its extension to evaluate other hemolytic effectors. BioMed Research International, 2014, 15-17. https://doi.org/10.1155/2014/632971.

Quatrin, A., Pauletto, R., Maurer, L. H., Minuzzi, N., Nichelle, S. M., Carvalho, J. F. C., ... Emanuelli, T. (2019). Characterization and quantification of tannins, flavonols, anthocyanins and matrix-bound polyphenols from jaboticaba fruit peel: A comparison between Myrciaria trunciflora and M. jaboticaba. Journal of Food Composition and Analysis, 78(January), 59-74. https://doi.org/10.1016/j.jfca.2019.01.018.

Ravindran, R., \& Jaiswal, A. K. (2016). Exploitation of food industry waste for high-value products. Trends in Biotechnology, 34(1), 58-69. https://doi.org/10.1016/J.TIBTECH. 2015.10.008.

Sun, Y., \& Li, L. (2018). Cyanidin 3-glucoside inhibits inflammatory activities in human 
fibroblast- like synoviocytes and in mice with collagen- induced arthritis. Clinical and Experimental Pharmacology and Physiology, 45(October 2017), 1038-1045.

Wu, S. B., Dastmalchi, K., Long, C., \& Kennelly, E. J. (2012). Metabolite profiling of jaboticaba (Myrciaria cauliflora) and other dark-colored fruit juices. Journal of Agricultural and Food Chemistry, 60(30), 7513-7525. https://doi.org/10.1021/ jf301888y.

Wu, C.-C., Hung, C.-N., Shin, Y.-C., Wang, C.-J., \& Huang, H.-P. (2016). Myrciaria cauliflora extracts attenuate diabetic nephropathy involving the Ras signaling pathway in streptozotocin/nicotinamide mice on a high fat diet. Journal of Food and Drug
Analysis, 24(1), 136-146. https://doi.org/10.1016/J.JFDA.2015.10.001.

Wu, S., Long, C., \& Kennelly, E. J. (2013). Phytochemistry and health bene fits of jaboticaba, an emerging fruit crop from Brazil. Food Research International, 54(1),

148-159. https://doi.org/10.1016/j.foodres.2013.06.021.

Zhao, D. K., Shi, Y. N., Petrova, V., Yue, G. G. L., Negrin, A., Wu, S. B., ... Kennelly, E. J. (2019). Jaboticabin and related polyphenols from jaboticaba (Myrciaria cauliflora) with anti-inflammatory activity for chronic obstructive pulmonary disease. Journal of Agricultural and Food Chemistry, 67(5), 1513-1520. https://doi.org/10.1021/acs.jafc. 8 b05814. 